\title{
TRACING OF ATMOSPHERIC AEROSOL SOURCES USING STABLE CARBON ISOTOPES
}

\author{
A. Garbaras, J. Andriejauskienè, R. Barisevičiūtè, and V. Remeikis \\ Institute of Physics, Savanoriu 231, LT-02300 Vilnius, Lithuania \\ E-mail: garbaras@ar.fi.lt
}

Received 25 July 2008; accepted 18 September 2008

\begin{abstract}
The identification of the pollution sources of incoming carbonaceous aerosols (total aerosol mass and $\mathrm{PM}_{2.5}$ ) at the Preila environment background station (Lithuania) during a winter period (2008) using the stable carbon isotope ratio $\delta^{13} \mathrm{C}$ is presented. For air mass transport analysis the Hybrid Single-Particle Lagrangian Integrated Trajectories (HYSPLIT) model was used. During the experiment the aerosol carbon isotopic ratio $\delta^{13} \mathrm{C}$ ranged from $-24.0 \pm 0.1$ to $-30.9 \pm 0.28$. The measurement data of the total aerosol mass particle $\delta^{13} \mathrm{C}$ values had not shown a significant variation and did not depend on the air mass transport directions. The mean $\delta^{13} \mathrm{C}$ value of these aerosol particles was $-25.5 \pm 0.78$ o. It can be attributed to the local aerosol particle origin and it is of the same order as that of marine aerosol $\mathrm{PM}_{2.5} \delta^{13} \mathrm{C}$ values. The $\delta^{13} \mathrm{C}$ values for the aerosol particles $\mathrm{PM}_{2.5}$ transported from longer distances depended on the air mass transport directions. The mean value of $\delta^{13} \mathrm{C}(-30.9 \pm 0.28$ o $)$ of aerosol particles in the continental air masses of the eastern direction was lower than that of aerosol particles in relatively clear marine air masses of the western direction ( $-24.0 \pm 0.1$ to $-25.4 \pm 0.38 \mathrm{o})$. In the cases of other air mass transport events, samples $\left(\mathrm{PM}_{2.5}\right)$ collected at the Preila site were a mix of aerosol particles from the marine environment and anthropogenic (fossil fuel combustion products) pollution sources.
\end{abstract}

Keywords: aerosol, $\mathrm{PM}_{2.5}$, carbon isotopic ratio

PACS: $92.20 . \mathrm{Bk}$, 91.65.Dt, 91.62.La

\section{Introduction}

Investigations of the chemical composition of aerosol particles, their origin and evolution are of great importance in perceiving the processes of the climate change, environment pollution, and the atmosphere self-cleaning. The atmospheric aerosols absorb and scatter direct solar radiation and the Earth's feedback thermal irradiation as well as they change the thermal balance of the planet. Aerosol particles absorb gases, various chemical substances and compounds, and have impact on the water vapour condensation processes. They take part in the processes of the admixture dynamics in the atmosphere, stimulate photo-catalytic reactions, and therefore affect the global atmospheric chemistry.

The total carbonaceous aerosol comprises a complex mixture that is mainly classified into two fractions: elemental carbon, also called black carbon or soot, and organic carbon. The recently carried out scientific research $[1,2]$ has shown that the origin, properties, and behaviour of carbonaceous aerosols in the atmospheric processes are determined by organic com- pounds formed either by burning biomass and fossil fuel or natural compounds forming on the sea surface, in forests, etc. Organic compounds such as polycyclic aromatic hydrocarbons $\mathrm{PAH}$, oxy-PAH, and nitro-PAH are potential mutagens or carcinogens that have been found in urban particulate matter. Due to high sorption capacity and optical properties, black carbon particles originated from biomass and fuel burning are also of great importance to the atmospheric processes and they are a good indicator of anthropogenic air pollutants.

The progress achieved by performing experimental investigations and applying modelling results allows a quantitative assessment of the influence of various sources on the organic aerosol composition as well as forecasting their total optical thickness (optical and radiative properties of the atmosphere). However, the accuracy of the assessment results is limited because it is difficult to evaluate the origin of carbonaceous aerosols, their sources and scattering depending on the air mass transport and the climate parameters. Some attempts were made to study stable carbon isotopes in the marine environment for evaluation of the carbonaceous aerosol origin [3]. 
In this work the results of experimental research are presented, the basis of which is the investigation of ${ }^{13} \mathrm{C} /{ }^{12} \mathrm{C}$ variations $\delta^{13} \mathrm{C}$ of stable carbon isotopes in total carbonaceous aerosols and in aerosol particles with the diameter less than $2.5 \mu \mathrm{m}$ (i. e., $\mathrm{PM}_{2.5}$ ) depending on the air mass transport. The main aim of the work is to identify the origin of carbonaceous aerosols and the location of the anthropogenic pollution source. For the identification of the pollution source location and origin the investigations of relative variations of other isotopes are also used. For example, lead isotopic ratios are used for tracing the urban atmospheric aerosols [4], radioactive plutonium isotopes in the identification of radioactive pollution sources [5]. However, investigations of $\delta^{13} \mathrm{C}$ variations are especially expedient as they can characterize the dynamics and balance of the carbon cycle, the location of industrial pollution sources, and the impact of air mass transported pollution in the investigated region. The $\delta^{13} \mathrm{C}$ method is finding an increasing use for the investigation of the particle pollution in urban air [4], in studies of the marine environment [6], as well as for the investigation of $\delta^{13} \mathrm{C}$ differences between aerosols from major continental and oceanic sources, showing that aerosol particles over the ocean in the Northern Hemisphere are mainly of the continental origin, while those in the Southern Hemisphere are mostly of the marine origin [7].

\section{Carbon isotopic ratios in the environment}

In the environment the ${ }^{12} \mathrm{C}$ isotope makes up $98.89 \%$ of all naturally occurring carbon, the ${ }^{13} \mathrm{C}$ isotope makes up $1.11 \%$, while radiocarbon ${ }^{14} \mathrm{C}$ only $10^{-10} \%$.

The isotopic composition is a relative isotope distribution of the analysed chemical element, usually the ratio of a less distributed isotope to the more widely distributed isotope: ${ }^{2} \mathrm{H} /{ }^{1} \mathrm{H},{ }^{13} \mathrm{C} /{ }^{12} \mathrm{C},{ }^{15} \mathrm{~N} /{ }^{14} \mathrm{~N}$, etc. In the present-day literature the isotopic ratio is determined using the dimension of $\delta$ specifying (usually in thousandths, $8_{0}$ ) the deviation from the chosen standard. For example, for carbon $\delta$ is

$$
\delta^{13} \mathrm{C}=10^{3} \frac{\left({ }^{13} \mathrm{C} /{ }^{12} \mathrm{C}\right)_{\text {sample }}-\left({ }^{13} \mathrm{C} /{ }^{12} \mathrm{C}\right)_{\text {standard }}}{\left({ }^{13} \mathrm{C} /{ }^{12} \mathrm{C}\right)_{\text {standard }}} .
$$

It is generally agreed that the standard is the Cretaceous period calcite, $\mathrm{CaCO}_{3}$ (Belemnitella Americana or PDB). The carbon isotopic ratio ${ }^{13} \mathrm{C} /{ }^{12} \mathrm{C}$ in this calcite is measured very exactly with a special mass spectrometer and equals $0.0112372 \pm 0.0000090$ [8].

In the geophysical, chemical, biologic, and other processes occurring in the geosphere the ratio of above- mentioned isotopes varies very slightly. Some examples of $\delta^{13} \mathrm{C}$ are presented in Fig. 1 [9]. The maximum difference is observed between carbonates, atmospheric $\mathrm{CO}_{2}$ gas, and fossil fuel. A large difference is observed among plants, which are distinguished by different photosynthesis mechanisms. The most widely spread mechanism of carbon fixation is called the Calvin cycle and it is denoted as $\mathrm{C}_{3}$. It is typical of most trees, bushes, grass, etc. Another mechanism $\left(\mathrm{C}_{4}\right)$ is called the Hatch-Slack cycle. Typical representatives of this cycle are sugarcane and maize. We have measured the ratios of carbon isotopes for some plants growing in Lithuania. The samples were collected during the vegetation period. The value of $\delta^{13} \mathrm{C}$ ranged from $-28.2 \pm 0.4$ to $-30.1 \pm 0.28$ o. These values correspond to the $\mathrm{C}_{3}$ type plants and are in agreement with the published data (Fig. 1). The diagram presented in Fig. 1 shows that different environments, which can be sources of both anthropogenic (fossil fuel and biomass burning) and natural (marine, forest origin organic compounds) atmospheric aerosols, are distinguished by certain $\delta^{13} \mathrm{C}$ values of the carbon isotopic ratio. They can be "fingerprints" in identifying the origin and sources of natural and anthropogenic atmospheric aerosols.

\section{Methods}

Atmospheric aerosol particles were collected on the $47 \mathrm{~mm}$ diameter quartz-fibre filters. The exposure time was 24 hours and the amount of pumped air was $55 \mathrm{~m}^{3}$. The fraction of aerosol particles of the aerodynamic size less than $2.5 \mu \mathrm{m}$ was separated using the LECKEL separator. The quartz-fibre filters were baked before sampling at $600^{\circ} \mathrm{C}$ for 3 hours to remove organic impurities. After sampling they were stored in a refrigerator. The filters were analysed with the elemental analyzer FlashEA 1112 connected to the stable isotope ratio mass spectrometer ThermoFinnigan Delta Plus Advantage. The $1 / 8$ th part of the filter was placed into the tin capsule and combusted in the oxidation furnace at the temperature of $1020^{\circ} \mathrm{C}$ and with the oxygen excess. Carbon of the sample oxidized into $\mathrm{CO}_{2}$ gases. Later this gas was transferred into the reduction furnace $\left(650^{\circ} \mathrm{C}\right)$. The water from the sample in the helium flow was removed using the magnesium perchlorate trap (Fig. 2). Then the gas mixture was separated in the column PoraPlot $Q\left(50^{\circ} \mathrm{C}\right)$. Separated gas was delivered to the mass spectrometer ionization cell through the gas distribution device ConFlow III. 
${ }^{13} \mathrm{C}$ atom $\%$

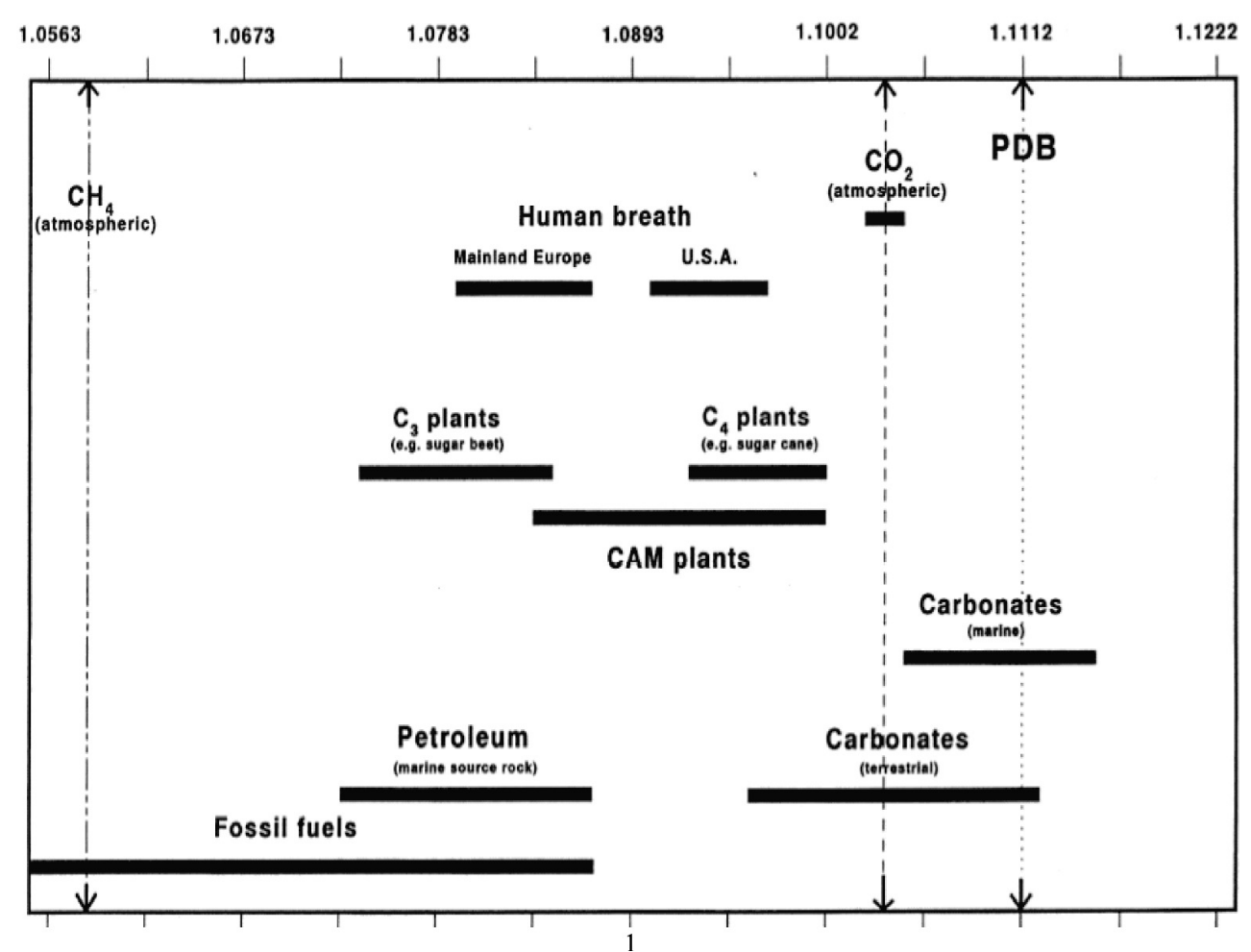

Fig. 1. Some typical examples of natural $\delta^{13} \mathrm{C}$ values grouped according to the origin along the scale of ${ }^{13} \mathrm{C}$ natural abundance [9].

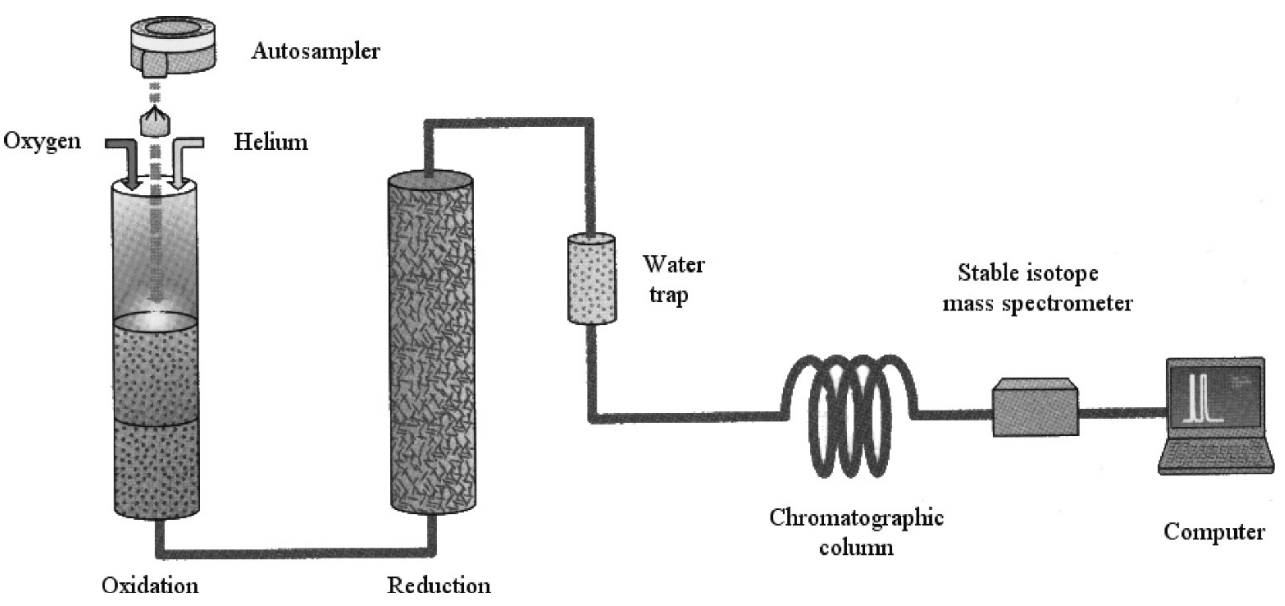

Fig. 2. System for bulk carbon isotopic ratio determination.

Before the analysis of a series of samples the calibration $\mathrm{CO}_{2}$ gas was delivered to the mass spectrometer until the isotopic ratio recurrence more than $0.15 \%$ was achieved. Before determination of the carbon isotopic ratio and after determination, the calibration gas was delivered to the mass spectrometer. According to the first signal of the calibration gas, the isotopic ratio of the sample was calculated, and according to the second signal the measurement conditions were controlled.

\section{Results}

The investigations were carried out at the Preila environment background station (Lithuania). The station is located on the eastern Baltic Sea shore $\left(55^{\circ} 22^{\prime} \mathrm{N}\right.$, $21^{\circ} 02^{\prime} \mathrm{E}$ ). The nearest source of anthropogenic pollution, the Klaipeda city, is at the $50 \mathrm{~km}$ distance. Thus, carbonaceous atmospheric aerosols were transported to the Preila site by continental and marine air masses. As the main aim of the study was to identify the origin of incoming carbonaceous aerosols, the HYSPLIT air 


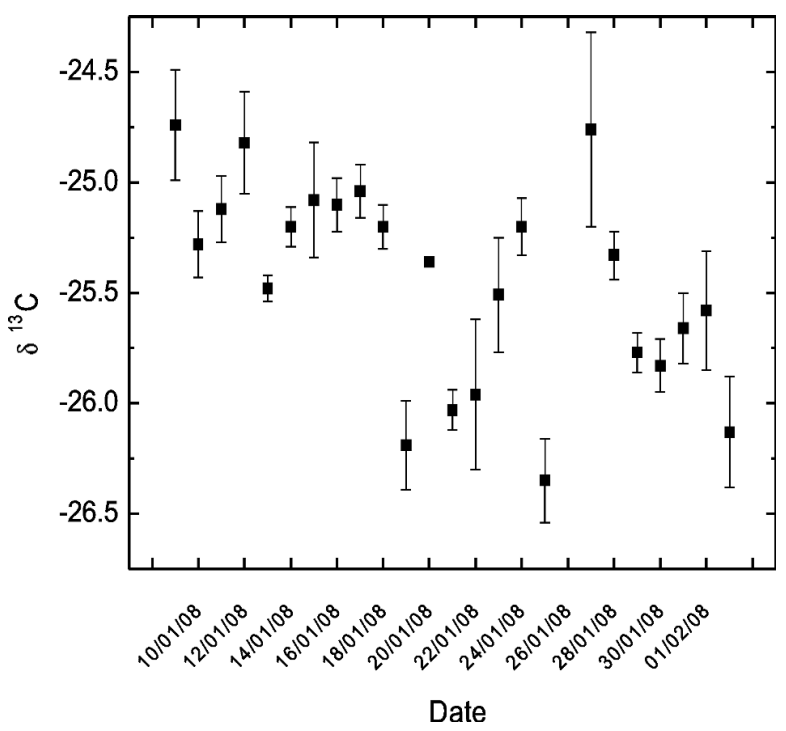

Fig. 3. $\delta^{13} \mathrm{C}$ in total aerosol mass at the Preila background station during 9 January - 2 February 2008.

mass backward trajectory model was used for the analysis of results [10].

The experiment was performed during two sampling periods. The first period lasted from 9 January to 2 February 2008. Aerosol particles on the filter were collected not separating them into fractions (total aerosol mass). During this period, air mass transport from the west dominated at the Preila site, though some was from the northern or southern directions. The air mass transport to the Preila station from the eastern or southeastern directions was not observed. Bearing in mind that collected samples were of the coarse aerosol fraction with the lifetime of the order of one day, from backward air mass trajectory analysis it is evident that during this sampling period most of the sampled aerosols were transported with marine air masses from the Baltic Sea. For this air mass transport scenario the carbon isotopic ratio values $\delta^{13} \mathrm{C}$ were from $-24.7 \pm 0.3$ to $-26.4 \pm 0.28$ o. From the experimental data (Fig. 3) it follows that the mean $\delta^{13} \mathrm{C}$ value is $-25.5 \pm 0.78$ o for the total aerosol mass. Because the total aerosol mass is mostly influenced by the mass of largest particles, it is evident that this $\delta^{13} \mathrm{C}$ value characterizes aerosol particles from local areas. This value indicates that the aerosol formation is affected by the marine and other natural precursors, for which the isotopic ratio value is common in this region, i. e. with the relatively clean atmospheric marine air and background environment.

The second sampling period lasted from 23 March to 16 April 2008. For the aerosol size separation the LECKEL $\mathrm{PM}_{2.5}$ sampler was used. This size range of aerosol particles was chosen because the lifetime of the $\mathrm{PM}_{2.5}$ size aerosol is from a few days to one week, and it allows us to collect aerosol particles transported from longer distances. During this period air masses were transported from the eastern (Ukraine and Belarus), northwestern (Scandinavia and the Baltic Sea) directions, and local spread over Lithuanian, Latvian, Polish, and Kaliningrad (Russia) territories. For this period the air mass 72-hour backward trajectories were analysed. The examples of air mass transport trajectories and $\delta^{13} \mathrm{C}$ measurement data are shown in Fig. 4. The measured $\delta^{13} \mathrm{C}$ values and trajectories show that the carbon isotopic ratio $\delta^{13} \mathrm{C}$ in air samples depends on the air mass transport direction. The measured $\delta^{13} \mathrm{C}$ values can be divided into three groups presented in Fig. 4 together with backward air mass trajectories typical of each group. Bearing in mind that the mean $\delta^{13} \mathrm{C}$ value of aerosol from the local region was $-25.5 \pm 0.78$ o (Fig. 3), it is evident that the middle data group (see Fig. 4) consists of a mix of aerosol particles from the marine environment and anthropogenic pollution sources. The upper data group (Fig. 4) indicates aerosol particles mostly of the marine origin with $\delta^{13} \mathrm{C}$ values ranging from $-24.0 \pm 0.1$ to $-25.4 \pm 0.38$ o. The bottom data group (eastern air mass transport events) clearly indicates anthropogenic pollution sources (mean $\delta^{13} \mathrm{C}$ value $-30.9 \pm 0.28$ o)

Experimental data very closely coincide with the carbonaceous aerosol concentration variation measured at the Preila site [11]. The highest concentrations of carbonaceous aerosol were observed in the continental air masses, and the lowest ones in the marine air masses. The most negative $\delta^{13} \mathrm{C}$ values in our experiment are measured in aerosols transferred by the continental air masses. It confirms that transported aerosol particles partly consist of the fossil fuel combustion products, the $\delta^{13} \mathrm{C}$ values of which are lower than -308 .

\section{Conclusions}

The stable carbon isotopic ratio method is applicable for the identification of atmospheric carbonaceous aerosol sources. During the experiment (winter period, 2008) the aerosol carbon isotopic ratio $\delta^{13} \mathrm{C}$ ranged from $-24.0 \pm 0.1$ to $-30.9 \pm 0.28$ o at the Preila environment background station.

The measurement data of the total aerosol mass $\delta^{13} \mathrm{C}$ values had not shown a significant variation and they did not depend on the air mass transport directions. The mean $\delta^{13} \mathrm{C}$ value of these aerosol particles was $-25.5 \pm 0.78$ o. It can be attributed to the local aerosol 


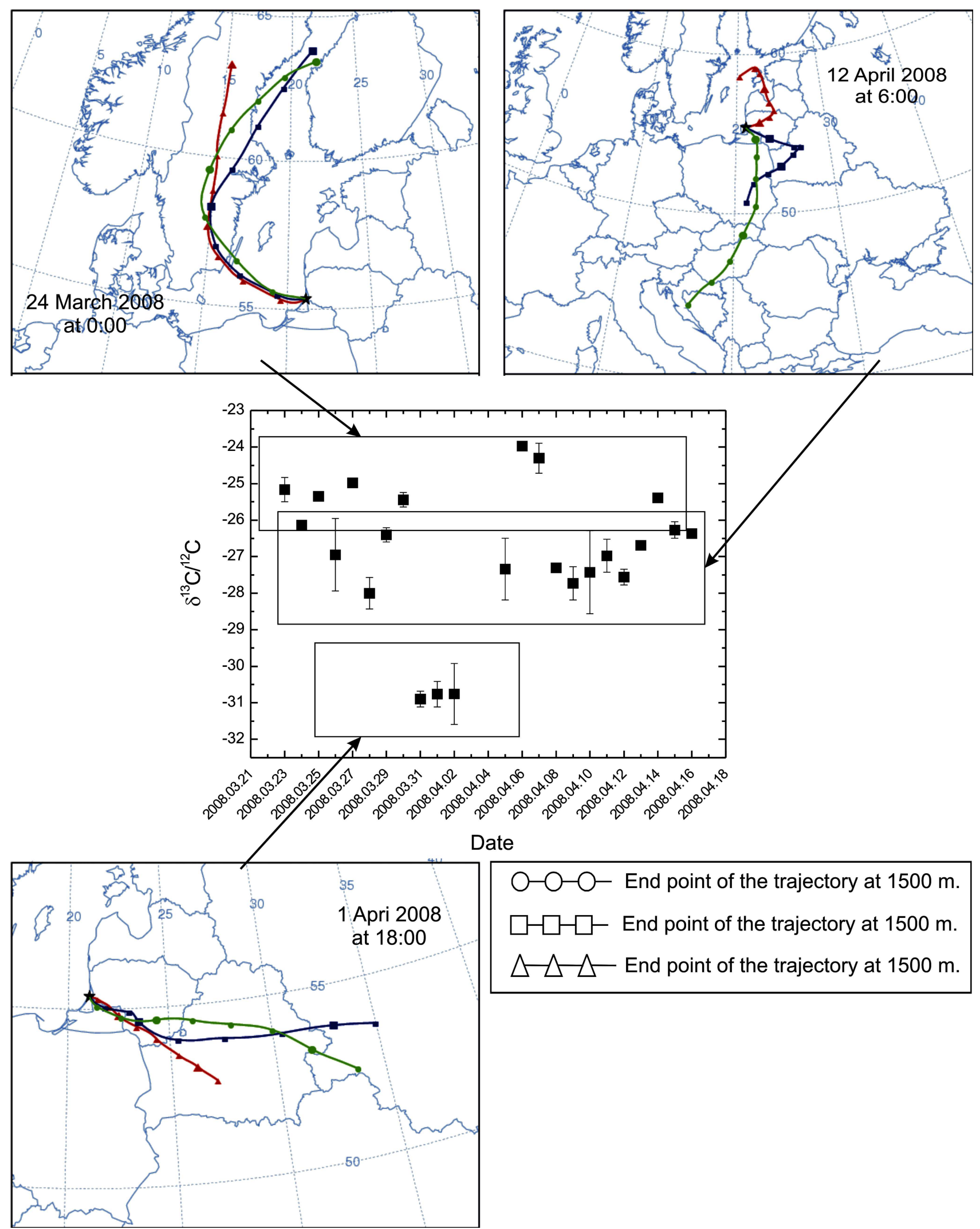

Fig. 4. Carbon isotopic ratio $\left(\delta^{13} \mathrm{C}\right)$ in aerosols $\left(\mathrm{PM}_{2.5}\right)$ and air mass backward trajectories (23 March - 16 April 2008). 
particle origin and it is of the same order as that of marine aerosol $\mathrm{PM}_{2.5} \delta^{13} \mathrm{C}$ values.

The $\delta^{13} \mathrm{C}$ values for the aerosol particles $\mathrm{PM}_{2.5}$ transported from longer distances depended on the air mass transport directions. The mean value of $\delta^{13} \mathrm{C}$ $(-30.9 \pm 0.28$ o $)$ of aerosol particles in the continental air masses of the eastern direction was lower than that of aerosol particles in relatively clear marine air masses of the western direction $(-24.0 \pm 0.1$ to $-25.4 \pm 0.38$ o). In the cases of other air mass transport events, samples collected at the Preila site $\left(\mathrm{PM}_{2.5}\right)$ were a mix of aerosol particles from the marine environment and anthropogenic (fossil fuel combustion products) pollution sources.

\section{References}

[1] S. Menon, J. Hansen, L. Nazarenko, and L. Yunfeng, Climate effects of black carbon aerosols in China and India, Science 297, 2250-2253 (2002).

[2] C. Venkataraman, G. Habib, A. Eiguren-Fernande, A.H. Miguel, and S.K. Freindlander, Residential biofuels in South Asia: Carbonaceous aerosol emissions and climate impacts, Science 307, 1454-1456 (2005).

[3] J.D. Court, J.R. Goldsack, L.M. Ferrari, and H.A. Polach, Use of carbon isotopes in identifying urban air particulate sources, Clean Air 15, 6-11 (1981).

[4] D. Widory, S. Roy, Y. Moulec, G. Goupil, A. Cochere, and C. Guerrot, The origin of atmospheric particles in
Paris: A view through carbon and lead isotopes, Atmos. Environ. 38, 953-961 (2004).

[5] V. Remeikis, R. Gvozdaite, R. Druteikienè, A. Plukis, N. Tarasiuk, and N. Špirkauskaitè, Plutonium and americium in sediments of Lithuanian lakes, Nukleonika 50, 61-66 (2005).

[6] P.A. Raymond, The composition and transport of organic carbon in rainfall: Insights from the natural $\left({ }^{13} \mathrm{C}\right.$ and ${ }^{14} \mathrm{C}$ ) isotopes of carbon, Geophys. Res. Lett. 32, L14402 (2005); doi:10.1029/2005GL022879.

[7] H. Cachier, Isotopic characterization of carbonaceous aerosols, Aerosol Sci. Technol. 10, 379-385 (1989).

[8] J.T. Brenna, T.N. Corso, H.J. Thobias, and R.J. Caimi, High-precision continuous-flow isotope ratio mass spectrometry, Mass Spectrom. Rev. 16, 227-258 (1997).

[9] W. Meier-Augenstein, Applied gas chromatography coupled to isotope ratio mass spectrometry, J. Chromatogr. A 842, 351-371 (1999).

[10] R.R. Draxler and G.D. Rolph, HYSPLIT (Hybrid Single-Particle Lagrangian Integrated Trajectory) Model access via NOAA ARL READY Website (http://arl.noaa.gov/ready/hysplit4.html) (NOAA Air Resources Laboratory, Silver Spring, MD, 2003).

[11] J. Andriejauskienè, V. Ulevičius, M. Bizjak, N. Špirkauskaitè, and S. Byčenkienè, Black carbon aerosol at the background site in the coastal zone of the Baltic Sea, Lithuanian J. Phys. 48, 183-194 (2008).

[12] A. Milukaite, K. Kvietkus, and I. Rimšelytè, Organic and elemental carbon in coastal aerosol of the Baltic Sea, Lithuanian J. Phys. 47, 203-210 (2007).

\title{
ATMOSFEROS AEROZOLIŲ ŠALTINIŲ NUSTATYMAS NAUDOJANT STABILIŲ ANGLIES IZOTOPŲ SANTYKI
}

\author{
A. Garbaras, J. Andriejauskienè, R. Barisevičiūtè, V. Remeikis
}

Fizikos institutas, Vilnius, Lietuva

\begin{abstract}
Santrauka
Pateikti stabilių izotopu santykio $\delta^{13} \mathrm{C}$ kaitos eksperimentiniai duomenys atmosferos aerozolio daleliu bandiniuose, surinktuose Preilos aplinkos tyrimu stotyje $2008 \mathrm{~m}$. Darbo tikslas buvo matuojant stabilios anglies izotopu santykius identifikuoti aerozolio dalelių šaltinius, priklausomai nuo atnešamų oro masių kilmès. Anglies izotopu santykiai matuoti stabilių izotopu masių spektrometru „ThermoFinnigan Delta Plus Advantage“. Aerozolio dalelių pernaša oro masemis analizuota naudojant 72 val. atgalines oro masių pernašos trajektorijas 1500,500 ir $50 \mathrm{~m}$ virš žemės paviršiaus. Trajektorijos skaičiuotos NOAA AIR (National Oceanic and Atmospheric Administration, Air Resource Laboratory, JAV) HYSPLIT modelio metodika [10]. Eksperimento laikotarpiu aerozolio dalelèse anglies stabilių izotopu santykis $\delta^{13} \mathrm{C}$
\end{abstract}

kito nuo $-24,0 \pm 0,1$ iki $-30,9 \pm 0,2$ o. Bendroje aerozolio dalelių masèje išmatuota stabilių anglies izotopų santykio vidutinè vertè, kurią lèmé stambios vietinès kilmès dalelès, buvo $-25,5 \pm 0,7$ o. Atneštu iš tolimesnių vietovių $<2,5 \mu \mathrm{m}$ dydžio aerozolio dalelių $\delta^{13} \mathrm{C}$ santykiai skyrèsi priklausomai nuo oro masių pernašos krypties. Rytinès pernašos kontinentinèse oro masèse $\delta^{13} \mathrm{C}$ vidutinè vertè $(-30,9 \pm 0,28$ o $)$ aerozolio dalelèse buvo mažesnè nei vakaru pernašos santykinai švarioje jūrinèje oro masèje (nuo $-24,0 \pm 0,1$ iki $-25,4 \pm 0,38$ o). Gauti rezultatai parodè, kad, vyraujant rytinei pernašai Preilos aplinkos tyrimų stotyje, dominavo antropogeninès kilmès anglies aerozolio dalelès. Nustatytos pietų krypčiu pernašos kontinentinèse oro masėse aerozolio dalelių $\delta^{13} \mathrm{C}$ santykio vertès (nuo $-26,1 \pm 0,1 \mathrm{iki}-27,7 \pm 0,68$ o) parodè, kad anglis aerozolio dalelèse yra iš ivvairių šaltinių (biogeninių bei iškastinio kuro degimo produktų). 